\title{
The Role of the State in Higher Education Reform: Mainland China and Taiwan
}

\author{
WING-WAH LAW
}

The higher education systems of mainland China and Taiwan, dominated by single ruling parties for more than 4 decades, are decentralizing concurrently with larger societal changes that began in the 1980s. Market forces now are incorporated into the socialist economy of mainland China, whereas opposition is institutionalized in Taiwan's national political structure. Despite disparate social transformations, formerly state-exclusive institutional powers are devolving to individual universities and colleges on both sides of the Taiwan Strait.

The former socialist countries in Central and Eastern Europe offer an interesting backdrop for an analyis of higher education in mainland China and Taiwan. Despite budgetary difficulties and problems of structural constraints and attitudes inherited from the old systems, higher education in these former socialist systems is now marked by three major characteristics of decentralization: diversification of institutional structures, curricula, and access conditions; the removal of political forces from campuses and the abolition of political and ideological education from the curriculum; and the acceptance of the state's guidance by means of finance, rather than political control. ${ }^{1}$

In contrast to the former socialist countries whose single ruling (communist) parties were overthrown, the two Chinese states have been commanded by their respective founding parties since the late 1940s: the Chinese Communist Party (CCP) in mainland China, and the Chinese Nationalist Party (CNP) in Taiwan. Moreover, decisions to redefine the domestic systems were made and implemented selectively by the respective Chinese ruling party organs in accordance with their sociopolitical or economic priorities, rather than by the people as occurred in the former socialist countries. As a result, the CCP and CNP select and limit the areas and degrees of power devolution to the two Chinese higher education systems.

This article identifies the patterns of higher education reforms in mainland China and Taiwan since the 1980s. The comparative motif argued here is that the ruling parties in mainland China and Taiwan

\footnotetext{
' See the special issues on higher education reform in the former socialist countries of Central and Eastern Europe, the European Journal of Education 28, no. 4 (1993), and the European Journal of Education 29, no. 1 (1994).
}

Comparative Education Review, vol. 39, no. 3 .

(C) 1995 by the Comparative and International Education Society. All rights reserved.

$0010-4086 / 95 / 3903-0004 \$ 01.00$ 
are principal actors in reshaping selectively the institutional structures, internal management, and curricula of their higher education systems. In response to domestic and international events during the 1980s, both Chinese ruling parties, while striving to sustain their political leadership, redefine their domestic systems piecemeal rather than as a whole. As a result, the reforms of the two higher education systems as part of selective social transformations are driven by different domestic forces: economic in mainland China, and political in Taiwan. However, common to both reforms is the devolution of institutional powers to universities and colleges, but within the institutional and curricular limits prescribed by the respective Chinese states. In particular, both Chinese states still hold the final decision-making powers over, for example, the appointment of university presidents, and, in the formal curriculum, both Chinese ruling parties insist on the provision of political and ideological education for all students.

\section{Comparative Developments in Higher Education}

After a series of civil wars, the political leadership in China was split between the CCP and CNP in 1949. The CCP remained in power in mainland China, and the CNP moved its seat to Taiwan which was returned to China in 1945 after 51 years of colonial rule by Japan. Since the geopolitical split, the two Chinese higher education systems have been developed separately by the two Chinese ruling party organs. Between the 1950s and 1970s, both higher education systems were part of their respective nation-building mechanisms and reflected their social systems' structural characteristics. Colleges and universities trained high-level personnel for economic modernization, but only those who qualified by passing state-required ideological courses.

\section{The Early Years}

During the founding periods, the CCP and CNP modeled their respective higher education systems on those of the Soviet Union and the United States, but both also aimed at training high-level personnel for economic improvement. The mainland state restructured pre-1949 Republican higher education into a tripartite system similar to the former Soviet model, with emphasis on educating scientists and technologists for the construction of a new socialist China. The tripartite system was characterized by the division of labor between higher education institutes in training different types of specialists and was composed of three basic types of institutes: comprehensive universities (responsible for education in the natural sciences, humanities, and social sciences), single-faculty institutes, and multifaculty institutes. Until 1980, the mainland higher education system (including the degree and nondegree granting sectors) included 32 comprehensive universities, 378 institutes of applied sciences (engi- 
neering, agriculture, forestry, and medicine), 172 teacher-training institutes, and 93 colleges of other disciplines. ${ }^{2}$ As in the Eastern European socialist countries, higher education in mainland China was marked by overspecialization, the separation of the natural sciences from technology, and the shifting of research activities from universities to the Chinese Academy of Sciences and hundreds of research institutes under related ministries.

In contrast, in 1945 the Taiwanese state transplanted Republican Chinese higher education from mainland China to replace the Japanese model. The transplanted pre-1945 Republican Chinese higher education was adapted from the U.S. education system of the 1920 s. Consequently, Taiwanese students were exposed to such American characteristics as qualification through formal credits and an emphasis on general education. In the early 1950s, Japanese staff holding teaching and administrative positions were gradually replaced by Chinese professors who went to Taiwan with the CNP. After 1949, Taiwanese higher education (like other levels of education) was entrusted with a mission to train high-level personnel for constructing Taiwan as a "base and bastion for recovery of Mainland China," which first-generation leaders and their followers believed to be temporarily lost to the CCP. ${ }^{3}$ Also unlike mainland China, Taiwanese higher education supported the integration of the natural sciences with technology, and of research with teaching.

Because of their different economic systems, mainland China and Taiwan differed in their methods of financing higher education and treatment of the private higher education sector. In mainland China, all rival forces such as market and religion which the CCP perceived to be associated with capitalism were eliminated. Like other private institutions, all pre-1949 private colleges and universities, particularly those run by foreign associations (e.g., churches), were nationalized in the early 1950s; their ownership and administrative powers were transferred to the state. Beijing authorities saw this nationalization as a way to prevent foreign influence on Chinese educational affairs. As a result, all higher education institutions belonged to and were financed completely by the central government bureaucracy despite its small investment $(0.43$ percent of the gross national product [GNP] in 1980 and 0.47 percent in 1985). ${ }^{4}$ Until the early 1980s, higher education was free to all students who had access.

\footnotetext{
${ }^{2}$ Ministry of Education, Department of Planning and Construction, Achievement of Education in China: Statistics, 1949-1983 (Beijing: People's Education Press, 1984), p. 51.

${ }^{3}$ Ministry of Education, Bureau of Statistics, Education in the Republic of China, 1991 (Taipei: Ministry of Education, 1991), p. 20.

4 The expenditure of higher education and GNP of mainland China (in renmin bi [RMB] million yuan) were, respectively, 1,913 and 447,000 in 1980 , and 4,014 and 855,760 in 1985 . The data on higher education expenditure were taken from Ministry of Education, Department of Planning and
} 
Unlike its mainland counterpart, the Taiwanese state has accepted private-sector participation in the economy and education since the: 1950s. Financing higher education is diversified by allowing private colleges and universities to charge fees. The numbers of public and private colleges and universities were, respectively, seven and nine in 1961, and 28 and 22 in 1991. In the last 4 decades, public universities and colleges have relied mostly on national or regional governments for financial support, whereas private institutions have depended mainly on students' fees and partly on fund-raising and government subsidies. Undergraduate enrollment has been higher in the private sector since the 1960s; undergraduates in that sector increased from 25 percent (out of a total of 29,542) in 1961-62 to 60 percent (out of 153,088) in 1980-81, and to 59 percent (out of 253,462 ) in $1991-92 .^{5}$

Despite incorporating different foreign educational models and different methods of financing, both Chinese higher education systems before the 1980 s were marked by rigid centralization as a means to limit tertiary institutes', teachers', and students' deviation from plans and procedures outlined by the respective Chinese states. The mainland state administered its higher education through the State Education Commission (or Ministry of Education before 1985) and related ministries at various levels, and the Taiwan state directed its system through the Ministry of Education. Both Chinese states controlled, for example, the appointments of chief university executives and teaching staff, access to higher education, the use of the national language as the official medium of instruction, the curriculum, the use of textbooks and teaching references, the establishment of departments and institutes, and the allocation of material and human resources. Private colleges and universities in Taiwan, in spite of small subsidies from the state, were subject to curricular, budgetary, and administrative controls by the Ministry of Education that were similar to those imposed on the public institutions. ${ }^{6}$

In addition to these characteristics of centralization, the higher education systems of mainland China and Taiwan were also marked by politicizationthe ruling political parties' influence on such university affairs as administration, curriculum, and students' extracurricular activities. The first ex-

Construction, Achievement of Education in China: Statistics, 1949-1983, p. 371, and Achievement of Education in China: Statistics, 1986-1990 (Beijing: People's Education Press, 1991), p. 99. The GNP figures were in Zhongguo tongji nianjian, 1990 (Statistical yearbook of China, 1990) (Beiji.ng: China Statistics, 1990), p. 33.

${ }^{3}$ The percentages concerning education in this paragraph were calculated from the data in Zhonghuaminguo jiag'u tongji (Educational statistics of the Republic of China, 1992) (Taipei: Ministry of Education, 1992).

${ }^{6}$ For details, see Erwin H. Epstein and Wei-fan Kuo, "Higher Education," in The Confucian Continuum: Educational Modernization in Taiunn, ed. Douglas C. Smith (New York: Praeger, 1991), p. 182. 
pression of politicization in both Chinese higher education systems was their integration of university administration and politics, though in different forms. Within individual higher education institutions in mainland China, there were two contending power cores: a university administration team led by the president, and a local university party led by the party secretary. Local university party secretaries, however, had more administrative powers than university executives, and as admitted in the 1985 educational reform plan, they "monopoliz[ed] the management of everything." "Unlike mainland China, Taiwan's university presidents (particularly of national higher education institutions) usually were also heads of campus political organs, and even took up party posts outside campuses. Military officers - whose presence was most objected to by many Taiwanese university academics - were responsible for military training and, together with discipline committees, for monitoring students' behaviors in both private and public universities and colleges.

Another feature of politicization in the mainland and Taiwanese higher education systems was their emphasis on transmitting value systems advocated by the ruling parties in the formal curriculum. Passing political and ideological courses as part of admissions and graduation requirements was imposed on students in both higher education systems. After admissions, it was obligatory for mainland students to take courses such as Scientific Socialism, Political Economy, and the History of the Chinese Communist Party. Students from selected universities were required also to engage in military training. In Taiwan, the Ministry of Education stipulated that students take eight units (out of 128) of courses on the CNP's version of Chinese modern history and the thought of Sun Yixian. Since the early 1950s, students (both male and female) have been required to enroll in (noncredit) military courses on campuses, and male students to engage in military training outside campuses during the summer. Additionally, Taiwanese students were required to observe national flag raising on important occasions, as they did in primary and secondary schools.

Until the 1980s, extracurricular campus activities on both sides of the Taiwan Strait were dominated by the respective youth party forces. In mainland China, local Communist Youth Leagues assisted university parties in coordinating political activities to spread anticapitalist ideas and the thought of party leaders and in recruiting students into the CCP. On Taiwanese campuses, local Youth Leagues for Anticommunism and Saving the Nation helped party organs in spreading anticommunist ideas

${ }^{7}$ Reform of China's Educational Structure: Decision of the CPC Central Committee, May 1985 (Beijing: Foreign Languages, 1985), p. 20. 
among students and in nominating presidential candidates for student unions.

Thus, both Chinese higher education systems had contrasting institutional structures for science and technology and modes of financing in training high-level personnel for economic modernization. Yet, at least until the 1980s, both higher education systems were similarly subject to strict control by their respective states and were used aggressively as instruments of politicization. However, beginning in the 1980s, higher education as part of social structures in mainland China and Taiwan was reshaped when both Chinese states redefined their national identities (as claims of separateness grew compelling) within a new set of international and domestic parameters.

\section{The Contemporary Period}

Contemporary reforms of the higher education systems in mainland China and Taiwan occurred within a new international political and economic framework, especially after the global decline of communism in the late 1980s. Since the 1950s, both the mainland and Taiwanese states under the command of the respective ruling parties have defined nationhood in terms of international relations, particularly vis-à-vis the two superpowers - the United States and the former Soviet Union. Mainland China, in the 1950s, regarded the United States as a major enemy, while Taiwan rejected official links with the former Soviet Union and mainland China. Moreover, both Chinese countries have competed with each other for official recognition of their nationhoods by the international community. Despite the geopolitical split of leadership, both Chinese states made claims about their sovereignty over each other and their wish to take back territory from each other. As a result, they did not participate togrether in international events until the mid-1980s. Taiwan formerly represented the legitimate government of "China" in the United Nations under U.S. support but after 1971 was replaced by mainland China without U.S. objection. Unlike the CCP, which rejected Chinese traditions, particularly during the Cultural Revolution, the CNP as a retreating political party from mainland China to Taiwan portrayed itself "as a separate nation (vis-à-vis other nations) rooted in its own history, as a standard bearer of traditional values (vis-à-vis the PRC [People's Republic of China]) and as a cultural ideal (as distinct from ethnic reality)."

However, in the 1970s, mainland China began to normalize its diplomatic and economic relations with Western countries, particularly the United States, whereas Taiwan suffered political and economic setbacks

${ }^{8}$ Allen Chun, "From Nationalism to Nationalizing: Cultural Imagination and State Formulation in Postwar Taiwan," Australian Journal of Chinese Affairs, no. 31 (January 1994): 49-69. 
after being denied membership from the United Nations and other international organizations such as the World Bank and International Monetary Fund. The disintegration of the former Soviet Union and the global collapse of communism further undermined mainland China's advance of socialism and Taiwan's position of anticommunism in their claims of separateness. However, since the 1980s' policy change from mutual exclusion to coexistence in international activities, both Chinese states and their peoples have been drawn much closer than before through bilateral humanitarian visits, trading, and cultural and academic exchange activities.

The continuing pursuit of new national identities of mainland China and Taiwan is also reflected in the redefinition of their domestic systems. In order to cope with leadership challenges at home and abroad, the founding parties began in the mid-1980s to adopt a similar national rebuilding strategy by selectively restructuring their domestic systems.

Adopting disparate foreign economic models in the 1950s led to different economic results. On the basis of the Soviet economic model, the mainland state abolished the private sector and controlled the national economy by monitoring production quotas, prices, and wages through mandatory national plans. However, the mainland economy was marked by, for instance, its bias toward heavy industry despite 80 percent of its population living in rural areas, a weak scientific and technological infrastructure, poor productivity and low economic returns of state enterprises, huge deficits in the state budget, an unmotivated labor force, and the decline of living standards. ${ }^{9}$

On the other side of the Taiwan Strait, Taiwan utilized the infrastructural legacies left by the Japanese colonial administration and modified the American economic model by allowing market forces to exist within the framework depicted in national plans and under the guidance of the ruling party. In the 1950 s, more than 50 percent of such important enterprises as oil refineries and electricity in Taiwan belonged to the state. Unlike mainland China which is still struggling for economic modernization, Taiwan has developed since that period into one of the newly industrializing countries in the South Pacific Rim-with a high per capita GNP of U.S. $\$ 10,215$ in $1992 .^{10}$

Thus, within their respective contexts reforms in mainland China and Taiwan higher education are characterized by a continuing search

${ }^{9}$ Gordon White, "Changing Relations between State and Enterprise in Contemporary China: Expanding Enterprise Autonomy," in China's Changed Road to Development, ed. Neville Maxwell and Bruce McFarlane (Oxford: Pergamon, 1984), pp. 43-60; Jiaju Qian, "What Is Socialism with Chinese Characteristics?" New China Quarterly, no. 7 (January 1988): 14-16; and Tong Saich, China's Science Policy in the 80s (Manchester: Manchester University Press, 1989).

${ }_{10}$ Council for Economic Planning and Development (CEPD), Taiwan Statistical Data Book, 1993 (Taipei: CEPD, 1993), p. 1. 
for national identity. International forces, newly emerging domestic forces (market mechanisms in mainland China, and public political competition in Taiwan), and the states under the command of the founding ruling parties shape reforms in these two Chinese higher education systems.

\section{Contemporary Reforms}

Higher education reforms in mainland China and Taiwan are part of the nation-rebuilding process and are driven by different domestic forces: economic in mainland China, and political in Taiwan. However, both nations' reforms result in the devolution of institutional powers to higher education, but within the limits prescribed by the state.

\section{Marketization of Higher Education and Its Limits in Mainland China}

From the 1980s, the mainland state created a "socialist market" economy in which higher education is partially "marketized"; in other words, higher education services are paid for by nonstate forces including immediate users (like students) and end users (such as the labor market). The quantities (enrollment quota) and contents of services (curricula) are regulated through the mechanisms of supply and demand in the labor market. These market stimuli require changes in the mainland's higher education system on two major levels: the diversification of financing to release the state's budgetary burden, and the institutional integration of science and technology, and of education and research to facilitate the conversion of scientific and technological results for economic modernization.

\section{Financial Diversification}

From the early 1980s, higher education in mainland China is no longer a "free good" sponsored by the state alone. Higher education seekers including students and their potential employers are required to pay for it. This change in concept and policy is due to low governmental financial investment. The annual educational expenditure (2.5 percent of the GNP in 1992) is relatively low when compared with industrialized countries (5.7 percent) and the world average ( 3.6 percent). ${ }^{11}$ Many higher education institutes lack financial resources often up to one-third to one-half of their recurrent costs. ${ }^{12}$

In order to broaden the financing of higher education, the mainland government adopts three major methods: the establishment of commer-

\footnotetext{
"Renmin ribao haizaiban (People's daily, overseas ed.) (November 1, 1993), p. 3.

12 Deguang Yang, "Woguo ying jiji wendingde fazhan minban daxue" (mainland China should actively and stably develop higher education run by the people), Zhongguo gaojiao yanjiu (Chinese higher education research) (February, 1993), p. 11.
} 
cial enterprises within colleges and universities, the increase of student quotas supported by nonstate sources in state colleges and universities, and the creation of a private sector in higher education. In the late 1950s, universities and colleges were allowed to establish factories and farms to propagate to teachers and students revolutionary ideals of integrating theory and practice, of connecting mental with manual work. In the 1980s the mainland state introduced a "school-enterprise model" for economic purposes by converting the former politically based "school-factory model." The policy of "three-in-one combination"-the integration of teaching, research, and production-began to gain momentum. Many "tripartite associations or integrated complexes" (each comprising a university or college, one or more research institutes, and one or more production units) were created. In 1993, these complexes involved 877 higher education institutes, 7,351 enterprises, and 1,604 research units in 27 provinces and cities. ${ }^{13}$ Unlike the school-run factories of the 1950 s which were responsible for primitive industrial production, enterprises established by universities and colleges in the early 1990s conducted commercial activities in high technology exploration zones and agricultural experimental bases and cooperated with other enterprises to provide scientific and technological information services. ${ }^{14}$

As a result, many mainland higher education institutions have assumed a new identity - as commercial enterprises - to create profits on their own terms. In 1990, 1,026 universities and colleges made a total net income of RMB 1.08 billion yuan from the school-run enterprises; 62.2 percent of this sum was from colleges and universities under various ministries, and 35.8 percent from those under regional authorities. ${ }^{15}$ Some universities can have more enterprises than others; for example, Beijing University ran about 10 companies in 1992. These school-run enterprises even enjoyed tax exemption for selected products, for instance, in Hunan Province. ${ }^{16}$ Part of the profits gained by these school-run enterprises is reinvested in higher education institutions for academic purposes. For example in 1992, Beijing University spent RMB 8 million yuan of its enterprises' profits on improving faculty salaries and living conditions and on increasing research funds for science and technology. ${ }^{17}$

13 Zhongguo jiaoyu bao (Chinese education newspaper) (September 15, 1994), p. 3.

14 "Gaodeng jiaoyu tizhi gaige quanmian zhankai" (Full implementation of the reform of the higher education system), Renmin ribao haiwaiban (People's daily, overseas ed.) (March 1, 1993), p. 3.

${ }_{15}$ Qingjun Zhuo, ed., Zhongguo gaige quanshu: Jiagyu gaige juan (A complete work of China's reform: Educational reform) (Dalian: Dalian Publishing House, 1992), p. 36.

${ }^{16}$ Zhongguo jiaoyu bao (Chinese education newspaper) (January 7, 1993), p. 1.

${ }_{17}$ "Wu Qingji queshi xinsheng yinian junxun gaiwei ba xingqi" (Wu Qingii [president of Beijing University] confirms that military training will change from 1 year to 8 weeks), Huaqiao ribao (Overseas Chinese daily news) (March 26, 1993), p. 5. 
The second major method for increasing the income of universities and colleges is charging students and their potential employers. Before 1983 , higher education was free to those with access. Now, there are three groupings of students classified according to their financial support: the state, students' potential employing units, and students themselves or their families.

In addition to the majority of students who are recruited according to the state's plans, a second grouping of students are under a contractstudy form of scholarhip with their potential or current employers. This financial support source emerged in 1983, particularly in coastal cities with growing regional economies. These students are financed by employing units and trained by designated higher education institutions. Like those admitted according to government plans, these students must pass the national college entrance examination, though a good grade is not a prerequisite. ${ }^{18}$ After graduation, they will be assigned work in the contracted units. The number of contract-study scholarship students increased from 3,200 (less than 0.3 percent of the entire tertiary student population) in 1983 to 154,500 (7.5 percent) in $1991 .^{19}$

In 1986, public universities and colleges in mainland China began to admit the third grouping of students: those who are privately financed. The number of these students increased rapidly from 1,030 ( 0.18 percent of the total tertiary student population) in 1986 to 86,300 ( 11.4 percent) in $1992 .{ }^{20}$ After graduation, these students, unlike those sponsored by the state or production units, are free to choose their own jobs. However, self-financed students have to pay high tuition fees (about RMB 2,000 yuan per student in 1992-93) and accounted for about 30 percent of unit cost for training an undergraduate.

The mainland government imposed charges on the entire student population by means of miscellaneous fees in $1989 .{ }^{21}$ The policy of requiring students to pay tuition fees in public universities and colleges was included in the 1993 education reform plan and will be implemented gradually on a national scale. This means that the former provision of free higher education to students has been abolished. Students and their potential employers are required to pay for higher education services in the socialist market economy of mainland China.

${ }^{18}$ Ruiqing Du, Chinese Higher Education: A Decade of Reform and Development (1978-1988) (Basingstoke, Hampshire: Macmillan, 1992), p. 21.

${ }^{19}$ State Education Commission, The Development and Reform of Education in China, 1986-1988: A National Report on Education Presented to the 41 st Session of the International Conference on Education, Geneva, 1989 (Beijing: People's Education Press, 1989), p. 43; and State Education Commission and Shanghai Intellectual Development Research Institute, eds., 1991 Nian Woguo Jiagyu Shive Fuzhan Tongii Kuaibao (Brief statistics on the development of education in the People's Republic of China in 1991) (Beijing: State Education Commission, 1991), p. 25.

${ }^{20}$ Renmin ribao haiwaiban (People's daily, overseas ed.) (June 14, 1993), p. 1.

${ }^{21}$ Ibid. 
The third means for the mainland state to release its financial burden is the reintroduction in the early 1990s of the formerly banned private sector in higher education. In early 1993, there were 17 private fulltime, but small-scale, colleges registered with the mainland government. ${ }^{22}$ These private colleges grew very fast and by late 1993, the municipal education authorities in Shanghai alone approved the establishment of 90 such colleges. ${ }^{23}$ Many of these authorizations were initiated by prominent figures (such as retired high-ranking party cadres, entrepreneurs, educators, and philanthropists), funded by business enterprises, administered by retired university presidents or directors, and staffed by teachers in specializations recognized by the state or regional authorities. ${ }^{24}$ These private colleges offer courses mainly on practical subjects (like finances and the stock exchange, accounting, secretarial training for foreign trade, foreign languages, and hotel services) which gear closely with the developing market economy. However, students in these colleges are charged high tuition fees-equal to or higher than the tuition required of students in state universities. Teachers in private institutions are often from top universities and are given higher salaries than those in public universities and colleges.

Thus, introducing market forces into the "socialist" economy of mainland China allowed a shift in higher education from a reliance on financial state support to funding from different strata of the economy. Competition for funding from the nonstate sector, however, alters the structural relations between science and technology, and between research and teaching in many mainland universities and colleges.

Institutional Reintegration of Science and Technology, and of Research and Education

Before the 1980s, when the mainland followed the Soviet model of the separation of science and technology and of reduced research activities, the higher education system was biased toward the applied sciences. In 1980 there were only four universities of science and technology. There were three types of institutions that sponsored research: higher education institutions, the Chinese Academy of Sciences and its associated institutes, and research institutes under related ministries at various levels. Most basic and applied research projects were funded, respectively, by the latter two types of institutions. Because of limited governmental research resources and the unbalanced division of labor in research, universities and colleges comprised the smallest funding sector in contributions to science and technology research in mainland China. ${ }^{25}$

22 "Private Schools Thriving in China," Ming bao (Ming pao daily) (April 15, 1993), p. 58.

${ }^{23}$ Renmin ribao haiwaiban (People's daily, overseas ed.) (December 16, 1993), p. 8.

${ }^{24}$ Renmin ribao haiwaiban (People's daily, overseas ed.) (August 12, 1993), p. 8.

${ }^{25}$ Saich (n. 9 above), p. 72. 
The structural separation between science and technology and between research and teaching in the higher education system began to reverse only in the late 1970 s after the country opened up to Western notions that emphasized interdisciplinary studies among the natural sciences, the applied sciences, and technology. Another reason for the reversal was competition among higher education institutions for research funding associated largely with scientific or technological ventures for their own school-run enterprises or joint ventures with other enterprises.

The institutional reintegration of science and technology into the higher education system was further supported by university executives and academics in the 1980s. Some top administrators of comprehensive universities (institutions that were less competitive than institutes of technology in obtaining funding from the private sector) urged the establishment of such practical fields of study as technology and managernent, while also maintaining theoretical disciplines. ${ }^{26}$ These administrators believed that comprehensive universities could provide better theoretical foundations for technologies and different kinds of specialists for the development of interdisciplinary studies and applied research.

In the 1980s, with the support of university executives and academics, many comprehensive universities began to incorporate technological disciplines into their knowledge structure. For example, Fudan University established the Institute of Technology in 1984, and 1 year later Beijing University established the Institute of Economics (comprising economics, economic management, and international economics) and such departments of applied sciences as environmental science, sociology, and national economics and management. Many interdisciplinary studies were also established in comprehensive universities. Thus, Nankai University between the early 1980s and 1992 introduced 13 new fields of study-including electronic technology, biochemistry, biophysics, and economic information management.

This trend of broadening the knowledge structure also occurred in institutes of technology. Unlike comprehensive universities, institutes of technology incorporated fundamental sciences and humanities into their institutions beginning in the mid-1980s. For instance in 1987, Qinghua University and Huazhong Institute of Engineering incorporated natural

${ }^{26}$ Dezi Wang, "Gaodeng jiaoyu bixu zhongshi xueke jianshe" (Higher education institutes should emphasize the construction of fields of study), Gaojiao zhanxian (Higher education front), no. 12 (1984): 11-12; Aoqing Tang. "Zenyang ba zhongdian daxue bancheng liangge zhongxin" (How to make key universities become teaching and research centers), Gaojiao zhanxian (Higher education front), no. 3 (1985): 5-7; and Shisun Ding, "Gaige xuexiao gongzuo zhudong shiying jingii he shehui fazhan de xuyao" (Reform the work of higher education institutes: Actively adapt to the needs of the development of the economy and society), Zhongguo jiagyu bao (Chinese education newspaper) (June 29, 1985). 
sciences and humanities into their curricula. ${ }^{27}$ By 1993, the Shanghai University of Technology had established new Institutes of Economy and Management, Humanities and Social Sciences, and International Exchanges.

However, those who supported incorporating research into mainland China's higher education faced structural constraints, particularly in the mid-1980s. These constraints were overspecialization in curriculum, minimal research funds and facilities, lack of formal graduate education (before the early 1980s), and an exaggerated emphasis on the role of the Chinese Academy of Sciences as a central scientific and technological research organ. ${ }^{28}$ Despite these impediments, however, university academics began to emphasize the research functions of higher education during this period. By 1988 , there were 1,715 research units $(801$ research institutes and 914 research divisions) established in the higher education system. In regard to fields of study, 15.7 percent of these research units were for the natural sciences, 42 percent for engineering and technology, 13.1 percent for agriculture, 25.9 percent for medical science, and $\mathbf{3} .3$ percent for interdisciplinary research. ${ }^{29}$ Because of the gradual strengthening of infrastructure and human resources, higher education's contribution to science and technology research for economic modernization is increasing in mainland China. At the national level, mainland universities and colleges supported, for example, more than half of the Project of March 1986 emphasizing frontier science and technology exploration: 56.2 percent between 1987 and 1990 , and 58 percent in $1993 .{ }^{30}$ At the municipal level, the percentage of research projects in, for example, Shanghai's 50 universities was increased from 23.2 in 1988 to 39.4 in 1991. ${ }^{31}$

The emphasis on research for economic modernization in higher education in mainland China is displayed by the institutionalization of postgraduate education. In the early 1980s, higher education institutions began to recruit master and doctoral students; in 1991, 411 institutes offered courses for 80,500 postgraduates. ${ }^{32}$ The local teaching and research teams have been strengthened by the return of about 60,000 (31.6 percent out of 190,000) Chinese scholars and students who were trained in such

\footnotetext{
${ }^{27}$ Renmin ribao (People's daily) (September 19, 1987).

${ }^{28}$ Leo A. Orleans, "Soviet Influence on China's Higher Education," in China's Education and the Industrialized World, ed. Ruth Hayhoe and Marianne Bastid (New York and London: M. E. Sharpe, 1987), p. 195.

${ }_{29}$ State Statistical Bureau, ed., Changes and Development in China, 1949-1989 (Beijing: Beijing Review, 1989), p. 49.

${ }^{30}$ Zhongguo jiagu bao (Chinese education newspaper) (September 15, 1994), p. 3.

"Shenghong Wang, ed., Gaodeng jiaoyu wei difang jingji fuwu (Higher education serves local economy) (Shanghai: Tongji University Press, 1992), p. 227.

${ }^{32}$ State Education Commission and Shanghai Intellectual Development Research Institute, eds. (n. 19 above), p. 25.
} 
industrialized countries as the United States and the Federal Republic of Germany between 1978 and 1992. ${ }^{33}$ As of December 1993, 272 institutes were approved by the state to offer Ph.D. courses and about 8,000 teachers to supervise doctoral students. ${ }^{34}$

Thus, introducing market forces into the economic system in mainland China helped the state to relieve its financial burden in higher education by incorporating funding from nonstate forces and to reverse the former institutional separation of science and technology and of research and education. However, these changes also modified the relations between higher education institutions, teachers, and students.

\section{New Relations between the State and Higher Education}

Since the economic restructuring in the 1980s, universities and colleges increasingly have gained institutional autonomy over the knowledge structure, teachers' salaries, admissions, and university administration. However, the government introduced new measures to limit the influence of market forces on all these areas except the knowledge structure.

At individual institutions, the state has yielded part of its control to market forces in science, technology, the social sciences, and humanities. Before 1978, the humanities and social sciences were underdeveloped due to the ruling parties' political preference for promoting MarxismLeninism and Mao Zedong's teachings over other schools of thought and philosophies. Now these two fields are facing further underdevelopment, but for economic rather than theoretical reasons. This threat is in regard to the allocation of resources, choice of students, and economic activities.

The allocation of material and human resources tilts toward disciplines (such as science and technology) directly related to the commercial activities conducted by universities and colleges. For instance, in 1992, higher education institutions in Shanghai directed an estimated 86 percent of their research projects to improving the municipal economy ${ }^{35}$ Courses in humanities and social sciences in mainland China have become increasingly unpopular among students; most prefer practical subjects like science and technology, and courses related to business and foreign trade. In 1993-94, the top five electives for third- and fourth-year students in Shanghai were economics, international trade, computing sciences, commodity studies, and foreign languages. In the Shanghai University of Technology and University of Finance and Economics, one-third of the students took computing and finance as electives in the first term of

${ }_{34}$ Renmin ribao haiwaiban (People's daily, overseas ed.) (February 26, 1993), p. 1.

${ }^{34}$ Renmin ribao haiwaiban (People's daily, overseas ed.) (December 13, 1993), p. 3.

${ }^{35}$ "Shanghai gaoxiao keyan zhongxin zhuauyi, mianxiang jingji jianshe zhu zhanchang" (Higher education changes its focus on science and technology research and orients toward economic construction), Renmin ribao haiwaiban (People's daily, overseas ed.) (February 6, 1993), p. 1. 
1993-94; it was reported that each classroom for these two electives was filled with $400-500$ students. $^{36}$ The trend toward practical subjects or business-related subjects is also evident in secondary students' choices of potential majors in their application for admission to higher education. For example, in a key secondary school in Beijing in 1993, more than 80 percent of the final-year students opted for business, foreign trade, and real estate as first priorities on their higher education applications, reflecting a pattern that alarms some scholars of the Chinese Academy of Social Sciences and Beijing University who believe that there will be critical shortages in literature, philosophy, and history. ${ }^{37}$

Research in the humanities and social sciences suffers because of the lower status of these fields. In order to compete for resources with faculty in other areas, some humanities and social science faculty are forced to run businesses unrelated to their academic professions and therefore spend less time and effort on their research. For example, the humanities faculty of Wuhan University established such companies as the Center of Communications and Market Surveys, the Consultant and Information Company for Overseas Chinese Investment, and the Management Consultant Firm. ${ }^{38}$ Thus, in addition to reducing the state's control over the balance among fields of study, introducing market forces gradually alters employment relations between university academics and the ruling party organ. Now, the state is no longer the only source of academics' income in the growing economy. Academics and other intellectuals such as writers in a climate of high inflation ${ }^{39}$ have to supplement their income and support their institutes by taking on a new economic role: doing commercial business on a part- or full-time basis (xiahai). In early 1992, teachers in the Electronic Engineering Department of Tianjin University were organized by the university's authorities to sell their research results at the science and technology fairs in the provinces of Shandong and Jiangsu. ${ }^{40}$ In Sichuan Province, some teachers of the 60 higher education institutions reportedly worked in factories and mines. ${ }^{41}$ Nankai University, which had four enterprises, established a "dual part-time system" for teachers to go to enterprises to do part-time jobs and for experts from

${ }^{96}$ Renmin ribao haiwaiban (People's daily, overseas ed.) (December 16, 1993), p. 3.

${ }^{37}$ Wenhui bao (Wenhui daily of Hong Kong) (August 28, 1993).

38 "Fahui shehui kexue 'yinxing tuili,' wuda wenke jiaoshi fuwu jingji" (Teachers on the arts faculty of Wuhan University tap the social sciences to serve the economy), Renmin ribao haiwaiban (People's daily, overseas ed.) (April 14, 1993), p. 3.

${ }^{39}$ Weifang Min, "Higher Education Finance in China: Current Constraints and Strategies for the 1990s," Higher Education 21 (1991): 151-61.

${ }^{40}$ Guangming ribao (Guangming daily) (May 31, 1992), p. 1.

41 "Shanghai gaoxiao keyan zhongxin zhuauyi, mianxiang jingii jianshe zhu zhanchang" (Higher education changes its focus on science and technology research and orients toward economic construction), p. 1. 
enterprises to teach in the university. ${ }^{42}$ In 1993 an estimated 20 percent of the teachers at 10 Beijing universities had left their teaching posts for business, and about 40 percent of those who remained and were under 35 years had a "second profession." ${ }^{33}$ In brief, the state has partially lost control over academics' salaries, teaching, research, and overall activities.

In order to increase academics' motivation and minimize their migration into other sectors of the economy, the CCP introduced a contract system in the early 1990s. The new employment system is aimed at regulating teachers' relations with the state. Teachers are no longer state cadres, but contracted employees of individual higher education institutions. ${ }^{44}$ In 25 municipal universities under this new system in Beijing, 627 teachers were dismissed and 142 teachers' contracts were pending for renewal in $1992 .{ }^{45}$ In Nanjing University in the same year, 254 staff members (out of 4,555 ) were dismissed or on a pending status. ${ }^{46}$ However, the conditions of contract renewal are determined by individual higher education institutions, rather than by the CCP. For example, in 1992 the criterion for renewing teachers' contracts in Xian Jiaotong University was the accomplishment of at leat 70 percent of their assigned work; lesser performance led to dismissal or delayed contract renewal. ${ }^{47}$

Another new practice that has changed the relations between the state and university teachers is increased salary according to teachers' performance and the financial situation of individual higher education institutions. Since 1993 teachers' salaries comprise a fixed amount from the state and a floating amount from the school: the ratio of these two sums depends on the amount of funding higher education institutions obtain from nonstate sources. ${ }^{48}$ In 1992, 90 percent of teachers' salaries in 25 Beijing municipal universites were fixed, and 10 percent were given according to the number of classes taught and amount of research conducted. ${ }^{49}$ Another example is Fudan University's fund of RMB 400,000 yuan for their teachers, 70 percent of which was based on teaching per-

42 "Mianshou shier xiang shui" (Twelve tax-free items), Zhongguo jiagyu bao (Chinese education newspaper) (January 7,1993 ), p. 1.

43 Xingdao ribao (Sing Tao daily news, Hong Kong) (August 25, 1993).

41 Article 24, in Central Committee of the Communist Party of China and State Council, "Zhong. guo jiaoyu gaige he fazhan gangyao" (Guidelines of China's educational reform and development), Wenhui bao (Wenhui daily of Shanghai) (February 27, 1993), p. 1.

45 "Beijing shishu gaoxiao shenhua neibu guanli tizhi gaige" (City universities of Beijing step up the reform of their internal administration system), Guangming ribao (Guangming daily) (March 27, 1992), p. 1.

46 "Nanjing Daxue shixing zonghe gaige" (Nanjing University implements comprehensive reform) Guangming ribao (Guangming daily) (April 9, 1992), p. 1.

17 "Xian Jiaoda zonghe gaige guanli tizhi" (Xian Jiaotong University reforms its internal administration structure) Zhongguo jiaoyu bao (Chinese education newspaper) (May 7, 1992), p. 2.

${ }^{48}$ Article 42, in Central Committee of the Communist Party of China and State Council, p. 1.

49 "Beijing shishu gaoxiao shenhua neibu guanli tizhi gaige" (City universities of Beijing step up the reform of their internal administation system), p. 1 . 
formance and the number of assignments and 30 percent on teachers' curriculum design. ${ }^{50}$ In 1991, the workload of 13 teaching departments in Beijing Normal University was increased by 30.4 percent, whereas in Beijing Engineering University one-sixth of the teachers without teaching or research duties no longer received salaries. ${ }^{51}$

A further measure creating new higher education relations with the state pertains to admissions. Since the mid-1980s, regular colleges and universities with the support of regional authorities may adjust the percentages of contract-study-scholarship and self-financed students. Reportedly, these percentages are in addition to the state-mandated enrollment quota prescribed by the State Education Commission's annual limits and vary by province, by university, and even by departments within the same institution. Higher percentages mean larger regular incomes for universities and colleges. In 1993, the authorities of Shanxi Province allowed higher education institutions to set this figure between 15 and 25 percent. ${ }^{52}$ Similarly, the authorities of Sichuan province admitted more contract-study-scholarship and self-financed students by cutting the quota for state-supported students. ${ }^{53}$ In 1992-93, 21 percent of students admitted into Shanghai's colleges and universities were self-financed, and 4 percent were commissioned by production units. ${ }^{54}$ However, the sum of these two figures in Shanghai Jiaotong University was 30 percent-higher than the 25 percent municipal average ${ }^{55}$ - and university authorities expected to raise this sum to 40 percent during the following year. In 1992-93, Beijing University's Department of Genetic Engineering admitted only students who pay tuition (60 in total) ${ }^{56}$ In other words, Beijing University did not distribute equally among departments the overall state quota for private tuition students, but instead, based figures on students' "marketability"-labor market demands and funding from nonstate sectors. The

50 "Fudan Daxue jiaoxue guanli" (The strict teaching management of Fudan University), Zhongguo jiaoyu bao (Chinese education newspaper) (April 14, 1992), p. 1.

51 "Neibu guanli tizhi gaige Beijing gaoxiao zhubu tuikai" (Higher education in Beijing gradually reforms its internal administration structure), Zhongguo jiaoju bao (Chinese education newspaper) (April 2, 1991), p. 1.

52 "Shanxi queli gaoxiao faren diwei" (The legal accountability of higher education was established in Shanxi Province), Zhongguo jiagyu bao (Chinese education newspaper) (January 6, 1993), p. 1.

ss "Shanghai gaoxiao keyan zhongxin zhuauyi, mianxiang jingji jianshe zhu zhanchang" (Higher education changes its focus on science and technology research, and orients toward economic construction) (n. 41 above), p. 1.

54 Shenghong Wang, "Seize the Opportunity: Switch Operational Mechanisms and Accelerate Reform and Opening of Shanghai's Higher Education," Gaodeng jiaoyu yanjiu (China higher education research), no. 1 (1993): 12.

${ }^{55}$ Renmin ribao haizuaiban (People's daily, overseas ed.) (November 20, 1992), p. 3.

56 "Beida shenwu gongcheng zhuanye quanbu zhaoshou zifeisheng" (The department of genetic engineering recruited only self-supported students), Renmin ribao haiwaiban (People's daily, overseas ed.) (February 19, 1993), p. 3. 
University of Zhejiang even claimed that it would become a "university of self-financed students" in the near future. ${ }^{57}$

The policy of admitting contract-study-scholarhip and self-financed students, in spite of broadening access to higher education, challenges the meritocracy principle. Such policy provides a second chance for students who had already been denied opportunity to higher education by the former selection system. ${ }^{58}$ For example, scholarship students benefited from a "10-20 [percent] 'discount' on minimum qualifications for admission"; ${ }^{59}$ in 1992 , state universities admitted self-financed students whose average entrance scores were 20 marks lower than those of other students. ${ }^{60}$ The private Shanda University in Shanghai admitted students in 1992 with an average entrance score of 391.5 - 13.5 marks lower than the national minumum ${ }^{61}$ - and some Shanda students were initially rejected by state higher education institutions because of poor grades in certain subjects on the national entrance examination.

This admission policy reinforces social disparities between urban and rural and between coastal and inland areas in mainland China. As a result of economic reform, the per capita gross domestic product has increased, yet still varies across the country. Despite the introduction of grants and loans to needy students, ${ }^{62}$ it is quite difficult for young people from average rural families (about 80 percent of the total population) to afford high tuition fees in both public and private colleges and universities. In 1993 , a self-financed student paid RMB 2,500 yuan a year in the field of humanities, RMB 2,700 yuan in science and technology, and RMB 3,000 yuan in the fine arts. ${ }^{63}$ Poor students, whether in urban or rural areas, may acquire access to higher education mainly through state plans or schemes of contract-study-scholarship offered by rural enterprises. In contrast, children of senior staff members of large companies and highranking party cadres, even with lower grades, have a better chance of pursuing tertiary education by paying high tuition fees. In Shanda University in 1992-93, 75 percent of 231 new students were from families of state cadres and scientists and technologists, 11 percent from families

\footnotetext{
${ }^{57}$ Renmin ribao haiwaiban (People's daily, overseas ed.) (November 20,1992 ), p. 3.

${ }^{38} \mathrm{Kai}-\mathrm{min}$ Cheng, Zhongguo jiagyu gaige (Reform of Chinese education) (Hong Kong: Commercial Press, 1992), p. 221.

${ }^{59}$ Vilma Seeberg. "Access to Higher Education: Targeted Recruitment Reform under Economic Development Plans in the People's Republic of China," Higher Education 25 (1993): 171.

60 "Beijing shi mingnian jianshao gaozhao kemu" (Beijing reduces the number of advancedlevel subjects), Guangming ribao (Guangming daily) (July 28, 1992), p. I.

${ }^{61}$ Xiao Xiao, "Minjian banxue de youyi changshi" (Interesting innovations in school:s run by the people), Shanghai gaojiao yanjiu (Shanghai higher education research), no. 2 (1993): 49.

${ }_{62}$ Shouxin Li and Mark Bray, "Attempting a Capitalist Form of Financing in a Socialist System: Student Loans in the People's Republic of China," Higher Education 23 (1992): 375-87.

${ }^{63}$ Renmin ribao haiwaiban (People's daily, overseas ed.) (August 4, 1993), p. 1.
} 
of teachers, 12 percent from families of workers, and only 1.4 percent from families of peasants. ${ }^{64}$

Despite the power devolution to individual higher education institutions, the state attempts to introduce institutional limits on the influence of market forces on higher education by insisting that the State Education Commission and regional authorities approve the admission quota of individual universities and colleges. In 1994, the State Education Commission further warned tertiary institutes against adjusting the prescribed admission plan and against recruiting more students than the prespecified quota. ${ }^{65}$

Another state-imposed limit on higher education is its control over the appointment and the definition of the powers of the presidents of state universities and colleges. The "president-responsibility system" was proposed in the 1985 educational reform plan to separate university administration from local party power. Under this system, university presidents were given more, yet still limited, managerial powers over institutional reorganization, personnel management, the raising and allocation of funding, and the adjustment of student quotas for self-financed and contract-study-scholarship students. ${ }^{66}$ At the same time, local party secretaries were given the duties to "strongly support the principals or presidents in the execution of their functions and powers, and to guarantee and supervise the implementation of the Party's various principles and policies and the fulfillment of the state's education plans." However, in 1985 only about 10 percent of higher education institutions were chosen to test the president-responsibility system, and only some powers were transferred from the university party committees to presidents. ${ }^{67}$ Since the Tiananmen Square incident in 1989, the state has suspended the pilot power separation policy in selected universities and colleges. ${ }^{68}$ Moreover, university presidents are still appointed by the state in spite of the fact that many departments were "elected." 69 The Central Committee even officially shifted the "president-responsibility system" back to "presidentresponsibility system led by the Party" in the 1993 education reform guidelines. ${ }^{70}$ The new system explicitly directs the reintegration of univer-

${ }^{64}$ Ming bao (Ming pao daily) (May 31, 1993).

${ }^{63}$ Zhongguo jiaoyu bao (Chinese education newspaper) (August 19, 1994), p. 1.

${ }^{66}$ Reform of China's Educational Structure: Decision of the CPC Central Committee (May 1985) (n. 7 above), p. 15.

${ }^{67} \mathrm{Du}$ (n. 18 above), p. 27.

${ }^{68}$ Kai-ming Cheng, "Zhongguo jiaoyu gaige he fazhan gangyao" (Guidelines of China's educational reform and development), Xinbao caijing xinwen (Hong Kong economic journal) (April 7, 1993).

${ }^{69}$ Kai-ming Cheng, Zhongguo jiaoyu gaige (Reform of Chinese education) (n. 58 above), p. 13.

${ }^{70}$ Article 38, in Central Committee of the Communist Party of China and State Council (n. 44 above). 
sity administration and politics, with the local university party committee resuming the highest decision-making role in each higher education institution and maintaining a "strong leadership core and fighting fortress" on campus. In Beijing, most municipal universities reportedly have already adopted the party-led president-responsibility system. ${ }^{71}$ Of the few exceptional institutions still allowed to test the pilot policy, all university party committees must function as "political cores."

Moreover, the state limits the establishment and ownership of private universities and colleges. As compared with public ones, private colleges and universities have more internal autonomy in personnel management because of less state administration interference, and their governing boards may appoint their own university executives including presidents. ${ }^{72}$ However, private universities and colleges are not totally free from state intervention: according to the "Provisional Regulation of the Establishment of Private Universities" promulgated in August 1993, the State Education Commission and regional educational authorities must approve their establishment. ${ }^{73}$ The daily administration of private higher education institutes is state regulated "through the adjustment of planning, the instruction in administration, and the assessment of goals." Moreover, nonmainlanders cannot possess the total ownership of individual private colleges and universities. Although the state welcomes partial or full funding from overseas (including Hong Kong, Macao, and Taiwan) to establish new private colleges, they must have local partners. ${ }^{75}$ This delineates the limit to which the state tolerates foreigners' influence on higher education.

In brief, in the process of institutionalizing market forces since the 1980 s, individual universities and colleges have acquired increasing institutional autonomy as a consequence of the diversification of their firancial sources and their important contribution to economic development in science and technology. ${ }^{76}$ However, the state also imposed constraints on higher education to regulate its institutional autonomy.

71 "Beijing shi gaoxiao neibu guanli, tizhi gaige qude chengxiao" (Success in the reform of internal administrative system in the higher education of Beijing), Zhongguo jiaoyu bao (Chinese education newspaper) (April 14, 1992), p. 1.

72 "Minban sili xuexiao zouhong shen cheng" (Schools run by the masses are popular in the city of Shen) Renmin ribao haiu'aiban (People's daily, overseas ed.) (February 24, 1993), p. 4.

${ }^{79}$ Ming bao (Ming pao daily) (August 25, 1993), p. Al6.

${ }^{74}$ Yang (n. 12 above), p. 12.

${ }^{75}$ This was expressed by an official of the State Education Commission in Beijing when $I$ held a "personal" talk with him in October 1993. The trip to mainland China was sponsored by the Central Research Fund of the University of London when I gathered information and conducted interviews for my doctoral thesis.

${ }_{76}$ Malcolm Tight, "So What Is Academic Freedom?" in Academic Freedom and Responsibility, ed. Malcolm Tight (Milton Keynes: Society for Research into Higher Education and Open University, 1988), p. 124. 
Depoliticization and Its Limits in Taiwanese Higher Education

Since the lifting of martial law in 1987, Taiwanese higher education has been depoliticizing - the process of removing ruling party political influences-albeit within political limits. This is demonstrated by the formation of university teacher associations, the election of the presidents of state higher education institutions, the rise of student forces, the inclusion of religious courses in higher education, and the establishment of the Institute of Taiwan History. In most areas, the state, however, has the opportunity to participate in final decision-making processes.

\section{University Teacher Associations as Public Forces}

University academics have had the opportunity since 1987 to form associations and express their views publicly. The state allowed university teacher associations (intervarsity and university based) to function as public forces and as political arenas for academics with and those without ruling party membership. Although initially the CNP banned its member teachers from participating in associations, with subsequent party encouragement CNP teachers have become mainstream forces in the standing committees, and their participation can, then, limit their policy direction and formulation. In National Taiwan University, the founders withdrew their membership and gave up their opportunities in the second election of the standing committee in $1989 .{ }^{77}$

An intervarsity teacher association, the University Reform Promotion Association (established in 1989), gained support of 961 teachers from 16 state and eight private higher education institutions. One of their projects has been to request a change in the relations between higher education and the state: from higher education as a state agent to an independent legal entity accountable to the law rather than exclusively to the state or the CNP. ${ }^{78}$ However, several university teacher associations preceded the formation of this intervarsity association. These associations made public demands for the withdrawal of political forces (including military officers) from universities, university autonomy in administration and curricula, abolition of political education, and freedom of publication. ${ }^{79}$ They also promoted the democratization of university administration - the official participation of teachers in the decision-making processes concerning management. In the late $1980 \mathrm{~s}$, academics recommended department heads and college deans in many national universities through internal election processes, and those selected were appointed by the university presidents. In National Chiaotung Univer-

\footnotetext{
${ }^{77}$ Wenjing Weng, "Qizhi xianming de ziyoupaijiti tuichu liao jiaolianhui" (The public withdrawal of liberal teachers from the University Teacher Association), Xin xinwen zhoukan (New newsweek) (June 26, 1989).

${ }_{78}$ The list of these supporters and their letter to the Legislative Yuan are in Defen He, Daxue zhi zaisheng (The rebirth of universities) (Taipei: Times Cultural Publishing House, 1990), pp. 254-69.

${ }^{79}$ See selected newsletters of these university teacher associations in ibid., pp. 360-66.
} 
sity all department heads have been elected and nominated by teachers since 1988; so too have been the Deans of the Colleges of Sciences and Engineering (since 1990) and the Dean of Management and Administration (since 1991). Therefore, since 1987, the formation of intervarsity and university-based teacher associations has created platforms for teachers to express publicly their disapproval against CNP control of higher education. However, demand by teachers (and students) for the depoliticization of the system would not be satisfied unless the CNP and the state devolved powers onto higher education.

\section{Election of the Presidents of National Universities}

The election of the presidents of Taiwan's national universities in the early 1990s was a struggle between the Ministry of Education and university academics. Before 1992, the Ministry of Education controlled the nomination and appointment of all national university presidents. In December 1992, after testing in five state universities and colleges, ${ }^{80}$ the Ministry of Education promulgated the Principles of Selection of the Presidents and Directors of National Universities and in 1993 attempted to use these principles to elect presidents of National Taiwan University and National Taiwan Normal University.

This proposal was marked by two contrasting characteristics: the broadening of university academics' participation in selecting their presidents, and the exercise of the state's control. According to the Principles of Selection, the candidates for presidency of a national higher education institution are firstly nominated at the university level by a selection committee composed of 9 to 15 members who are representatives from the teachers and alumni association of the university concerned, outstanding scholars outside the university, and officials of the Ministry of Education. The representing teachers may be decided by the university itself or appointed by the Ministry of Education, and they should number at least half of the total number of committee members. Moreover, successful candidates for presidencies must obtain the recommendation of two-thirds of the selection committee, after which it recommends two or three nominees to another state-led selection committee whose members are chosen and appointed by the Ministry for final consideration.

Academics of National Taiwan University and National Taiwan Normal University attempted to minimize the state's control over their future presidents in the nomination and selection processes in three ways: by forming a university-based selection committee, by diversifying the sources of nominees for president, and by requiring that the successful

${ }^{80}$ These higher education institutions were National Chiao Tung University, National Ocean University, National Chenghua University of Education, Provincial Tainan Teachers College, and National Kaoshiung Normal University. 
candidate not hold concurrent party and presidential offices. In early 1993, the academics of these two national universities objected to the formation of selection committees by the Ministry of Education. These academics insisted that the selection committees must be university based - that the committee members must be administrative and teaching staff of the universities concerned, and representatives from the Ministry of Education would not be accepted as members. In March 1993, the Minister of Education, Guo Weifan, responded to the persistence of these two universities by suspending the formation of state-involved selection committees at the university level. ${ }^{81}$ Thus, these two universities established their own selection committees and devised their own criteria for selecting their presidents. ${ }^{82}$

Further minimizing the CNP's control over their future presidents, these selection committees diversified the sources of applicants preceding the final nomination to the Ministry of Education for appointment. They stipulated that applicants for presidency must have support from either groups of academics or organizations - including professional associations, student unions, alumni associations, or the Ministry of Education. For National Taiwan Normal University, the Minister of Education declared that he would not nominate candidates to participate in the competition for the presidential post. ${ }^{83}$ However, two of the seven candidates who contended for university presidency were high-ranking officials in the Ministry of Education although they were nominated by academics.

Moreover, these two selection committees required the applicants for presidency to submit a letter declaring that if the Ministry of Education chose and appointed them as president, they would not concurrently take up party duties during their terms of office. This would mean discontinuing the tradition that the president of a national university usually carried out party duties on campus or in the public political structure. The President of Soochow University put this break from tradition into practice and resigned from the Central Committee of the National Assembly (the highest political body in Taiwan) in April 1993.

University academics in Taiwan have sought successfully an opportunity to select candidates for the Ministry of Education to consider, and, at the same time, to limit the Ministry's involvement. The efforts of National Taiwan University and National Taiwan Normal University and later Tsinghua University also forced the Legislative Yuan to stipulate the

${ }^{81}$ Zhongyang ribao (Central daily news) (March 5, 1993).

82 The two sets of criteria are in the Shida Xiaoxun (News bulletin of the National Taiwan Normal University), no. 71 (April 13, 1993): 3.

83 "Jiaoyubu buhui pairen canjia jingxuan shida xiaozhang" (The Ministry of Education will not nominate candidate for competition for the post of the president of the National Taiwan Normal University), Zhongyang ribao (Central daily news, international ed.) (April 16, 1993), p. 7. 
formation of university-based selection committees as educational policy in Article 6 of the new University Act passed in December $1993 .{ }^{84}$ However, the University Act designates that the Ministry of Education still holds the final power over the appointment of the presidents of national universities. Although there were Taiwanese scholars based in the United States who competed for the presidential posts of National Taiwan University and National Taiwan Normal University, the final candidates selected and nominated by university academics were former top executives of these two universities: Chen Weizhao, the former Director of the Medical College of National Taiwan University, and Lu Ximu, the former Dean of Academic Studies of National Taiwan Normal University (and also an ex-official of the National Science Council). They were appointed by the Ministry of Education without objection in mid-1993. From another viewpoint, the struggles for sectorial interests among contenders for presidency ${ }^{85}$ have not altered the reality that the appointment of these new presidents was an internal promotion, admittedly via a more complicated and "transparent" procedure by the Ministry.

Moreover, the CNP has continued to complicate the election of university presidents by linking scholarship with party duties: the incorporation of university academics into the party and state structures. This intertwining of politics and academia, a legacy of Chinese cultural heritage that may be summed up in the saying, "Be an official after being an excellent scholar" (Xue er you shi ze), is exemplified in the careers of a number of scholars and government officials. They include the current (1994) Minister of Defense who is the former president of National Taiwan University, Sun Zhen; the Minister of Transport who is the former president of Tsinghua University, Liu Zhaoxuan; and the Minister of Education who is the former president of National Taiwan Normal University, Guo Weifan. All were also elected members of the Central Committee in the Fourteenth Party Congress in August 1993. The "promotion" of the president of National Chengchi University and member of the Central Committee, Zhang Jingyu, to a ministerial member in 1994 created another chance for university academics to nominate their presidential candidate. In short, the ties between top university executives, the CNP, and the state prevent academics from broadening to its fullest their participation in university administration.

The Rise of Student Forces

The political struggles between university academics and the state were extended to the student level. Since 1987, Taiwanese students have

${ }^{84}$ See Article 6 in Lifayuan yian guanxi wenshu: Daxuefa (Documents of the Legislative: Yuan: The University Act), promulgated on December 7, 1993, p. 20.

${ }^{85}$ Ministry of Education, Daxuefa xiuzhengan (Revised draft of the University Act) (Taipei: Ministry of Education, 1993), p. 3. 
become another public force making claims against government policies, both on and off campuses. On campuses, students, like some of their teachers, insist on the separation of politics and university administration and on the broadening of their participation in university administration. For example, on May 11, 1993, students of National Chengchi University adopted legislative format in questioning state officials during their dialogue with university administrators. They demanded that the Sixth Party Group of the Northern League of Intellectuals (Bei-Zhi Qing) retreat from their campus and that the university president resign from the chair of the Party Group.

Expressing their opinions about educational policies through public actions, students have participated in such activities as a large-scale student movement that took place in Chung Cheng Square in Taipei, March 16-23, 1990. By adopting the model of the 1989 student movement in Tiananmen Square, thousands of Taiwanese students with their teachers' support demanded political reform. They asked President Li Denghui to make four political changes: to dissolve the National Assembly dominated by 700 old representatives elected in mainland China in 1948, to call a meeting for national affairs, to abolish the Temporary Provisions Effective during the Period of Communist Rebellion that allowed the president to be reelected without restriction to two terms, and to announce his political reform schedule. ${ }^{86}$ Students were allowed to express these ideas directly to $\mathrm{Li}$, but only after he was elected President. Then in December 1993 they went, again with some university academics, to the Legislative Yuan and Ministry of Education to protest against the passing of the new University Act which, they believed, endorses the continuation of political organs and forces on campuses. Some students returned in early 1994 to the Ministry of Education to protest against increased tuition fees.

Although student political activism has not become a threatening force to the CNP leadership, the state imposed stricter promotion criteria on students after expanding the tertiary enrollment quota in the early 1990s. From 1991, students would be expelled automatically if they fail more than half of the total units taken in any term, instead of more than twothirds: as a result, more students than before are expelled every term for academic reasons. The number of expelled students increased from 951 ( 0.42 percent of the total student population) in the second term of $1990-91$ to 2,116 (0.8 percent) in the first term of $1993-94 .^{87}$ In addition to maintaining student academic performance, the new policy of academic explusion arguably may have political implications for students. In an

${ }^{86}$ Jinshan He et al., Taibei xueyun (Student movement in Taipei, March 16-22, 1990) (Taipei: China's Times Publication Co., 1990).

${ }^{87}$ Gaojiao jianxun (Higher education bulletin), no. 37 (April 1994): 3. 
examination-oriented society like Taiwan, students may prefer to spend more time studying rather than organizing or participating in other nonacademic activities (including political affairs) in order to secure their posteducation posts.

\section{Establishment of Religious Courses}

In addition to creating chances for teachers and students to express publicly their opinions regarding higher education and politics, the CNP also broadened the curriculum in the transmission of religious valuesi along with state-prescribed political and ideological values. After the institutionalization of opposition, the Taiwanese state, unlike its mainland counterpart, began to tolerate religious pluralism (the official transmission of more than one religious value system) in place of the domination of a single religion in its higher education institutions. Before the mid-1980s, religious courses were not allowed in any higher education institutions, although there were some private universities, such as Fujen Catholic University and Chungyuan Christian University, run by churches. The first institute of religion was established for postgraduate students in Fujen Catholic University in 1987. For students at this level, the Ministry of Education in 1992 considered the possibility of establishing some institutes of a single religion (such as Buddhism and Christianity) for research ${ }^{88}$ However, for undergraduates-a much larger population than postgraduates-the Ministry of Education, despite its decision to incorporate religious courses into the general education curriculum, expressed the view in 1992 that these courses should be comparative and that no single religion should be propagated to students. ${ }^{8 c}$

In spite of the toleration of religious pluralism, the institutionalization of religion in higher education would not dilute the primacy of Sun Yixian's philosophies in political and ideological education. Until 1994, only Fujen Catholic University provided religious education for postgraduate students, but many national and private universities trained specialists in the studies of Sun's teachings. In 1990-91, there were only 19 postgraduate students of religion, but 169 master's students and 96 doctoral students were enrolled in the Institutes of the Three People's Principles. ${ }^{90}$ The depoliticization dimensions noted heretofore (formation of university teacher associations, selection of the presidents of national universities, rise of student forces, and institutionalization of religious courses) have demonstrated the political limits prescribed by the state. Yet tracing the establishment of the Institute of Taiwan History will show that academics themselves imposed some of these limits.

${ }^{88}$ Gaojiao jïanxun (Higher education bulletin), no. 14 (May 1992): 2.

89 "Daxue gaozhong jiaoxue naru zongjiao kecheng" (The incorporation of religiou: courses into secondary and higher education), Haizai xueren (Overseas scholars), no. 245 (April 19192): 15.

${ }^{90}$ Zhonghuaminguo jiaoyu tongii (mingguo 80 nian) (Educational statistics of the Republic of China, 1991) (Taipei: Ministry of Education, 1991), pp. 153-54. 


\section{Establishment of the Institute of Taiwan History}

In the early 1990s, part of the academic community still practiced selfcensorship - an act to avoid discussing issues in public that are deemed politically sensitive and challenging to the existing political leadership. In March 1993, the Academia Sinica decided to establish the Institute of Taiwan History to research the country's social, economic, and political development: the founding goal is to "upgrade Taiwan's standing in international academic circles by establishing strong theories and effective approaches to the study of Taiwan history." 91

However, the development of the Institute of Taiwan History has been limited by the constraints imposed by the government and the academic community. At present, the proposed research areas still need approval by the Office of the President of Taiwan. Some research fellows of the Academia Sinica have admitted that in order to avoid current politically sensitive issues, the institute will not carry out research on the problems of Taiwan's independence and its unification with mainland China, ${ }^{92}$ and the historical period to be studied will end with 1960. This year marked the beginning of the third term of the late President Jiang Jieshi-a violation of the constitutional limit. The year 1960 also saw a resumption of arrests of opposition leaders who advocated political pluralism and questioned the legitimacy of the CNP's political leadership ${ }^{93}$ (including the secretary of the New Party, Lei Zhen, and the editor of Free China, Fu Zheng). The carefully calculated avoidance by some Taiwanese academics to research these politically sensitive issues indicates that they still consider their "safety" when thinking about studies related to the political leadership, just as before 1987.

Thus, from the mid-1980s the Taiwanese state, unlike its mainland counterparts, has created a new political environment for higher education reform. Taiwanese academics and students are allowed to form new public forces as a leverage against the state. Like the marketization of higher education in mainland China, the incorporation of opposition into Taiwanese higher education initiated platforms for the negotiations between the state and university academics, as well as with students. This stimulated the state to change its education policy toward the selection of university presidents, student forces, religious curriculum, and the research on Taiwan's history. However, the Taiwanese state introduced limits, though different from mainland China, on higher education: the

\footnotetext{
91 Diana Lin, "Taiwan History Institute Heralded as a Milestone," Free China Journal (April 9, 1993), p. 4.

92 "Crucial Personnel of the Institute of Taiwan History," Zhongyang ribao (Central Daily News, international ed.) (March 29, 1993), p. 7.

${ }_{93}$ For details, see Xiaofeng Li, Taizuan minzhu yundong sishinian (Democratic movements in Taiwan in the last 4 decades), 3d ed. (Taipei: Zili Wanbao, 1989), chap. 2.
} 
diffusion of CNP academics into university teacher associations, the appointment of publicly elected presidents of national universities, the tightening of promotion criteria for students, and the domination of the transmission of approved national values. In addition, the legacy of selfcensorship among academics still remains.

\section{Parallel Political Limits Imposed on Higher Education Reforms in Mainland China and Taiwan}

Despite granting limited institutional autonomy to higher education as a result of different social transformations, both Chinese states imposed a parallel curricular limit on their higher education reforms: the maintenance of political and ideological education. In other words, both ruling parties continued to use their higher education systems as agents to propagate official beliefs to students for citizenship. The official beliefs include those revolutionary ideals and values prescribed by the political leaders of the first generation and those introduced by current leaders. However, the mixed sets of beliefs are disseminated through the transmission structure mainly created by the founding leaders.

\section{Strengthening of Political and Ideological Work in Mainland China}

In the early 1990s, the CCP political leadership was threatened by the global decline of communism, by the "negative" sociopolitical influences of domestic economic reform, and by its fear of the recurrence of the 1989 Tiananmen Square incident. After this event, the state tightened its grip on the political and ideological work in higher education-despite the decreasing interest of students and teachers in political orthodoxy-in five ways: by maintaining compulsory political and ideological courses, reasserting the importance of cultural transmission, controlling campuses, readjusting administrative personnel, and training teachers for ideological and political education.

Students are still required to pass compulsory political and ideological courses (both theoretical and practical). The content of textbooks for political and ideological education in some universities before and after the 1989 Tiananmen incident suggests that the state is attempting to revive the orthodoxy of the 1950s. ${ }^{9.4}$ Military training for new students of selected universities remains despite reducing the training period from 1 year to 8 weeks for Beijing and Fudan Universities in 1993-94. The 1994 "Guidelines of the Implementation of Education of Patriotism".further instruct all schools to set up additional classes and seminars on patriotism, to raise the national flag during opening and graduation ceremonies,

9 Ruth Hayhoe, "Political Texts in Chinese Universities Before and After Tiananmen," Pacific Affairs 66, no. 1 (Spring 1993): 21-43. 
and to ensure that students understand the meaning of the national flag and national anthem with messages emphasizing the CCP's contribution to the founding of the new socialist China. ${ }^{95}$

In order to maintain the formal and informal curriculum as a channel to transmit the ruling party's revolutionary ideals and values, the state frequently has emphasized the recruitment of party successors as an important cultural task of higher education in the early 1990s. In March 1991, the State Education Commissioner, Li Tieying, reasserted that ideological and political education was a means to ensure domestic political stability as well as the strength of the socialist system in mainland China. ${ }^{96}$ Higher education is still perceived as a "strong ideological weapon" against "decadent" capitalist influences introduced into the socialist economy and higher education. ${ }^{97}$ Higher education remains a state training center to recruit "reliable successors" for the ruling party-as measured against students' ability to "resist capitalist liberalization and all decadent thoughts of exploitation." 98 Training also emphasizes "successors with moral, intellectual, and physical development" and the improvement of the political qualities of teachers. These successors are supposed to possess four "haves" (morality, socialist ideals, culture, and discipline) and support three "isms" (patriotism, collectivism, and socialism). ${ }^{99}$

Moreover, the state also created CCP-controlled campuses in which official values were transmitted to students, despite the rise of student forces in the late 1980s and early 1990s. Since 1985, there have been five large-scale student demonstrations, the largest of which took place in Tiananmen Square and resulted in military suppression. The 1989 Tiananmen incident marked a limit in the toleration of the ruling party and the state in dealing with students' demands for economic and political reform. Prior to but notably since the incident, large numbers of police have patrolled university campuses, particularly on such anniversaries of "political significance" as May 4 and June $4 .{ }^{100}$ In July 1992, the educational authorities instructed colleges and universities to maintain "peaceful" cam-

\footnotetext{
${ }^{95}$ Articles 16, 31, and 34, in Central Committee of the Chinese Communist Party, "Aiguo zhuyi jiaoyu shishi gangyao" (Implementation guidelines for educating pupils with patriotism), Zhongguo jiagne bao (Chinese education newspaper) (September 6, 1994), p. 1.

${ }_{96}$ Tieying $\mathrm{Li}$, "Nuli jianshe you Zhongguo tese de shehui zhuyi jiaoyu tixi" (Diligently construct a socialist educational system with Chinese characteristics: 1991 report of the State Education Commission on January 24, 1991), Zhongguo jiagyu bao (Chinese education newspaper) (March 21, 1991), pp. 1,3 .

97 "Gaojiao yao jinyibu kuoda duiwai kaifang" (Higher education must open up more to the outside world), Renmin ribao haiwaiban (People's daily, overseas ed.) (July 3, 1992), p. 3.

${ }^{98}$ Article 3, in Central Committee of the Communist Party of China and State Council (n. 44 above).

${ }^{99}$ See the editorial in Renmin ribao haiwaiban (People's daily, overseas ed.) (June 26, 1993), p. 1.

${ }^{100}$ A. C. Grayling, "Academic Freedom," in June Fourth Briefing Papers on China, ed. Susan Whitfield (London: June 4th China Support, 1993), pp. 36-38.
} 
puses, ordering that ideas of "capitalist liberalization" should not be allowed to be transmitted on campuses and that no "earthquakes" (i.e., movements leading to social uprisings) should happen. ${ }^{101}$ The university authorities are given the duty to suppress these activities at their emergence.

In addition to controlling campuses, since 1989 the state has attempted to reclaim its administrative control from the presidents of higher education institutions. Between 1990 and 1992, 90 percent of top university executives were reappointed, ${ }^{102}$ more than half of whom had attended ideological and political training courses. Party members were "cleansed and reassessed" (qing li qing cha). In December 1993, more than 1,000 university executives and party leaders of key universities and colleges attended a training course emphasizing political and ideological work on campuses offered by the Institute of Advanced Educational Administration of the State Education Commission.

Finally, in reestablishing a teacher team for ideological and political education in the early 1990 s, the state now requires all teachers to raise their "ideological and political qualities" 103 and to teach in accordance with the policy of the CCP. ${ }^{104}$ Between 1982 and 1992 , about 6,000 teachers also received moral education training offered by the Beijing Research Committee of Moral Education in Higher Education. ${ }^{105}$ After the 1989 incident, young teachers attended theoretical courses on ideological and political education and participated in training relating to rural socialist education between 1990 and 1992. ${ }^{106}$ Some young teachers of Beijing University and Fudan University were selected to participate in student military training outside campus between 1989 and 1993.

In particular, the state attempted to improve the quality of teachers in ideological and political education in 1993. This special team was very large: there were 20,800 such teachers $(5.2$ percent of the total teacher population) in higher education in $1990 .{ }^{107}$ The state suggested that the qualification for the majority of these teaching positions be raised to a bachelor's or master's degree with a major in ideological and political education and that the remainder of these positions be filled with lecturers

101 "Gaojiao yao jinyibu kuoda duiwai kaifang" (Higher education must open up more to the outside world), sec. 3 .

102 Ibid., sec. 2

${ }^{103}$ Article 40, Central Committee of the Communist Party of China and State Council

${ }^{10}$ Yunxi Cui, "Wubi buyao hushi sixiang zhengzhi gongzuo" (Do not neglect ideological and political work), Zhongguo jiagyu bao (Chinese education newspaper) (January 6, 1993), p. 3.

105 "Beijing gaoxiao deyu yanjiu" (Study of moral education in Beijing higher education) Zhongguo jiagyu bao (Chinese education newspaper) (January 6, 1993), p. 1 .

106 "Gaojiao yao jinyibu kuoda duiwai kaifang" (Higher education must open up more to the outside world), sec. 2.

${ }_{107}$ State Education Commission, The Development and Reform of Education in China, 1988-1990: A National Report on Education Presented to the 42 nd Session of the International Conference on Eaiucation, Geneva, 1990 (Beijing: State Education Commission, 1990), p. 144. 
from other fields of study. ${ }^{108}$ The teachers in ideological and political education were also advised by the State Education Commission to use creative methods and modern educational technology to teach compulsory political and ideological courses, thereby ensuring that students have better than average educational resources in political education.

Thus, these five measures for tightening the political and ideological work in higher education suggest that the mainland state persists in using the curriculum, whether formal or informal, to train students for citizenship despite their increasingly prevalent loss of interest in political dogma and their increasing preference for studies related to the market economy.

\section{Sustenance of Ideological and Political Courses in Taiwanese Higher Education}

Like mainland China in the early 1990s, Taiwan made relatively few changes in the curricular transmission of the national belief system, in spite of its partial depoliticization. Teachers of political and ideological courses, students, and the ruling party resisted change. In 1991, the Ministry of Education attempted to integrate two ideological courses, the Thought of Sun Yixian and the Constitution of the Republic of China (Taiwan). The teachers of the Thought of Sun Yixian, like European academics who defended their "cultural" subjects at the emergence of industrialization in the nineteenth and early twentieth centuries, sought ruling party support and rejected the integration of these two courses. The controversy ended at the policy formulation level-only after the presidents of all higher education institutions showed their support for this change in June 1992. ${ }^{109}$

Students and university teachers of other courses also strongly objected to the Thought of Sun Yixian. In October 1992, the Ministry of Education commissioned a survey which shows that among 2,013 students (mainly third-year and from 23 public and private colleges), this course was the most "dissatisfying" as compared with other compulsory studies. ${ }^{110}$ Responding to these pressures, the Ministry of Education revised immediately the list of compulsory subjects common to all higher education institutions. Since 1993-94 the Thought of Sun Yixian and the Constitution of the Republic of China have been combined to form one new ideological course: the Constitution and Founding Spirit of the Republic of China.

${ }^{108}$ Xinjun Zhu, "Zhuazhu youli shiji jiaqiang he gaijin sixiang zhengzhi gongzuo" (Seize the favorable opportunity: strengthen and improve idcological and political work) Zhongguo jiagy bao (Chinese education newspaper) (January 6, 1993), p. 3. See also Article 29, Central Committee of the Communist Party of China and State Council (n. 44 above).

109 "Daxue bixiu kemu fuyu gengda kongjian" (Adopt a more flexible approach to compulsory subjects in higher education), Haizwai Xueren (Overseas scholars), no. 242 (October 1992), p. 16.

${ }^{110}$ Frank Huang, "On Teaching Improvement from 'The Survey of University Students to General Studies in Taiwan, [the] ROC"' (paper presented at the Symposium on Higher Education, National Taiwan Normal University, Taiwan, November 27-28, 1992). 
The CNP, which has maintained power during political reform, offered another source of resistance to the abolition of political education. The new ideological course is simply an incorporation of the Thought of Sun Yixian into the Constitution of the Republic of China. ${ }^{111}$ Moreover, the major purpose of the integrated course is the same as the old one: the transmission of official beliefs to students for citizenship. The state expects that this course will help students to develop the concept of clemocracy; to understand the founding spirit and ideals of Taiwan; and to learn about Sun Yixian's teachings, the constitution of Taiwan, and their integration with other contemporary trends. ${ }^{112}$ The CNP claims that the founding spirit and ideals of Taiwan are based on the Three People's Principles. In other words, as codified in the constitution and written in textbooks, the revolutionary ideals are to be disseminated in the higher education formal curriculum in the early 1990s. Additionally, students are still required to take the CNP's version of Chinese history. Military training remains compulsory for all first- and second-year students; failing this training means a student will not graduate. ${ }^{113}$

Finally, the University Act revised in 1993 continues to endorse ruling party political forces on campuses, despite the attempt to separate the functions between military offices and discipline committees in supervising students. According to the new Act, discipline committees in colleges and universities will be changed into student affairs committees responsible for counseling and extracurricular affairs, but military officers will remain in one of the highest campus roles-responsible for military training and nursing for students. The Ministry of Education considers that "whoever demands the retrieval of military officers from campuses is the one who causes harm to the nation, people, and students." However, others posit that the continuing existence of military officers would affect "academic freedom" and hamper the "democratization of society."114

The CNP's insistence on the propagation of Sun Yixian's teachings in higher education is now used to resist potential incorporation by mainland China. The global decline of socialism and the increase in Taiwan-mainland China nondiplomatic ties have undermined the cultural task of transmitting anticommunist ideas to students. Moreover, the CNP upholds that the future unification of Taiwan and mainland China should be

${ }^{111}$ Quanxiang Hong, Zhonghuaminguo xianfa yu liguo jingshen (The constitution and founding spirit of Taiwan) (Taipei: You Shi, 1993); Rixu Yang, preface to Hong, pp. 5-7.

${ }^{112}$ See the "Revised List of Common and Compulsory Subjects," Guoli jiaoyu ziliao guan guanxun (Bulletin of the National Educational Information Institute), no. 19 (December 1992): 24.

"113 Point 11 of the "Key Points of the Implementation of Common and Compulsory Subjects," Guoli jiagyu ziliao guan guanxun (Bulletin of the National Educational Information Institute), no. 19 (December 1992): 25.

114 "Jiaoguan zai xiaoyuan paihuai buqu" (Military officers still hang around campusesi, Yazhou zhoukan (Asian weekly) (December 19, 1993), p. 28. 
framed under the principle of "one country one system"-a "democratic and pluralistic society that has a free economy and a culture in harmony with daily life." 115 The potential unified China would be a "democratic, free and equitably prosperous China." 116 Teaching the constitution and the founding spirit of Taiwan is, then, an important way for Taiwan to preserve its own cultural and political identity in spite of the lack of official international recognition in the early 1990s. This is also consistent with one of the Taiwanese national defense policies: "The best way to ensure the safety of Taiwan is to nurture its power of resistance against the threat of the Chinese communists."117

Therefore, resistance is offered in both Chinese states to removing political and ideological education from the higher education curriculum. The CCP and CNP struggle for the continuation and legitimization of their political leadership and for their national identities in the international community. The mainland state struggles to preserve Chinese socialism against the global withering of communism by restructuring its economic system. The Taiwanese state can no longer use anticommunism as an easily available stance but must rely mainly on the preservation of Chinese traditional culture and the political traditions founded by Sun Yixian and on concomitant reform of the political system.

\section{Conclusion}

Higher education reforms in mainland China and Taiwan beginning in the 1980s have not taken place in a vacuum, but rather emerged with and have been affected by changes in domestic and international contexts. Mainland China introduced market adjustments into the socialist economy, and Taiwan incorpoated opposition into the political structure. Reforms in both Chinese higher education systems have been shaped by four main interrelated forces.

1) The international context is marked by a reorientation of economic, military, political, and ideological dimensions and by the struggles of many countries to redefine their national identities during such global realignment.

2) Newly emerging domestic nonstate factors (especially market forces in mainland China and the new middle class and political elite in Taiwan) are promoting wider participation in decision-making processes that were

115 "Adjustments in Policies: Changes are Underway in Long-Term Policies on Taiwan-Mainland Unification and Immediate Practical Issues Concerning Developing Relations," Free China Review (January 1991), p. 20.

${ }^{116}$ National Unification Council, Guidelines for National Unification (Taipei: Mainland Affairs Council, 1991).

${ }_{117}$ Ministry of National Defense (Taiwan), Zhonghuaminguo bashier bashisan nian guofang baogaoshu (National defense report of the Republic of China, 1993-94) (Taipei: Liming, 1994), p. 65. 
formerly exclusive to the states. There are demands for the improvement of the states' performance and accountability to the public.

3) The Chinese states are still under the command of the founding ruling parties which face problems of political legitimacy, but have become increasingly "sensitive" and "responsive" to the international enviroriment and domestic social demands.

4) Higher education is gaining increasing institutional autonomy with the support of the new domestic nonstate actors (including university academics from within and other forces from without) but is subject to new versions of administrative and political constraints imposed by the ruling parties.

The CCP and the CNP play a central role in nation-rebuildings processes and in higher education reform. They continue to be the: only actors with sufficient authority to formulate and implement policies on a long-term basis and to monitor university administration. Although both Chinese governments have abandoned their policy of rigid centralization to regulate in detail the functioning of individual colleges and universities, this does not mean that higher education is free from party intervention. Indeed, the autonomy of higher education institutions is still conditioned on the states' terms, and not on their own. Both the CCP and the CNP set regulations within which university executives (and local university party leaders in the case of mainland China) may perform daily management functions on their own. Despite their disparate social and political conditions, the current approach to reform in university administration and curriculum adopted by both Chinese states may be summed up in a simple formula: to have a firm grip on political and ideological affairs, but to devolve institutional powers in other arenas.

Higher education reform in these contending Chinese states is shaped by the pursuit of national identities. However, a process of decentralization in both systems has begun, despite the imposition of institutional and curricular limits by the respective Chinese ruling parties. Whether the trend will be reversed or the limits reduced (or even lifted) is unpredictable as both the CCP and the CNP are still struggling for the maintenance of their political leadership. When new sets of international and domestic forces emerge, relations between higher education and the state in mainland China and Taiwan may be revised and the reform formula redrafted. Whatever the results, the autonomy of higher education in mainland China and Taiwan, as in many other countries, is a status to be gained through long and subtle negotiation between state government and academic institutions. 